\title{
DEVELOPING EDUCATIONAL GAME AS LANGUAGE ACQUISITION MEDIA FOR YOUNG LEARNERS
}

\author{
Farid Helmi Setyawan \\ STKIP Modern Ngawi \\ faridhelmi@stkipmodernngawi.ac.id \\ Sofyan Susanto \\ STKIP Modern Ngawi \\ sofyansusanto@stkipmodernngawi.ac.id
}

\begin{abstract}
Language acquisition is the process of language mastery done by children naturally when they learn their mother of tongue. The era of globalization with the presence of sophisticated technology requires children to be able to use technology well. With the presence of technology, it makes it easy for children to learn many things, especially languages. The purpose of using language learning media based on the educational game culture character of the android system is to increase language acquisition for early childhood. With this language learning media, early childhood is helped in understanding and mastering verbal vocabulary. In addition, in this era, many people have Smart Phones that can load various applications. In addition, it is very easy for parents to access or open an android-based media application from their Smart Phones. The research method used is research and development. This development was carried out in the learning media, namely language learning media based on the educational character of the culture system of the android system. This study uses the Borg and Gall development theory which has been simplified into six stages. This research was conducted at PAUD / TK in the Ngawi Regency, East Java. The research subjects are early childhood and parents in PAUD/TK Ngawi Regency with a total of 50 people. The results of this study are in the form of educational learning applications based on the educational game culture character of the Android system. The results of the data analysis showed that, from 50 respondents who are parents of children, 44 people stated that the media ere feasible and very useful and 45 people gave positive responses. From the results of the addition of the acquisition of children's language shows 46 children experienced progress and the addition of the acquisition of a new language. The results of this study are expected to facilitate early childhood in language acquisition.
\end{abstract}

Keyword: language learning media, educational games, android system, language acquisition 


\section{INTRODUCTION}

Teaching and learning process can be interpreted as a series of processes of interaction between children and teachers in order to achieve their goals (Makmun, 2004: 156). In the teaching and learning process there is a process of learning behavior in children and the process of teaching behavior in the teacher. The process does not take place from one direction but rather occurs reciprocally where both parties play a role and act actively. In teaching and learning there is a stage where children are asked to understand a material. This is not an easy thing because children have different understandings. In language learning, especially the acquisition of a new language is very difficult and requires extra understanding for an early child.

One effort to optimize the achievement of children's learning outcomes in learning activities in particular understanding of the material can use learning media that is easy to use. Learning media is a means or tool for the process of teaching and learning (Daryanto, 2009: 419). Learning media can be divided into three types, namely: (1) Auditive Media; (2) Visual Media; (3) Audiovisual Media (Wina Sanjaya, 2014: 172).

The benefits of learning media for children are that it can make it easier for children to understand a material and arouse children's desire to learn, and even bring psychological influence on the child. In addition, learning media also allows children to learn independently according to their interests and abilities. Learning media is also one of the learning resources that can be used to increase the involvement of children in learning activities so that children gain direct learning experience. Whereas for instructional media teachers function to direct the thinking process of children to be able to find their own answers and make it easier to teach a concept of learning material.

In this study, instructional media that were compiled and developed were language learning media based on the educational game of cultural character of the Android system to help improve language acquisition for early childhood. The learning process emphasizes on giving direct experience to children to know firsthand the meaning and explanation of new terms by using language learning media based on the educational game culture character of the android system. Android-based educational media is the application of learning models in accordance with the era of the industrial revolution 4.0 where digital information has become a part of life. Information from the media especially TV, are very influence to the development of children's language.

Media can be called a tools, it means that media can be used in the learning process with the goal to making ways of communicating more effective and efficient. By using media the teacher and children can communicate more steadily and interactive and the interactions are multi-directional.

Media contains messages as stimulants of learning and can foster motivation to learn so that children do not become bored in achieving learning goals. The use of media in the implementation of teaching will help smoothness, effectiveness and efficiency in achieving goals. Lesson material that is manipulated in the form of teaching media makes children as if engrossed in and working with the media and of course the teaching will be meaningful. 
Language acquisition is the process of humans gaining the ability to capture, produce, and use words for understanding and communication. According to Stork and Widdowson (1974: 134), language acquisition is a process of children achieving fluency in their mother tongue. According to Lyons (1981: 252), language acquisition is a language that is used without qualifications for the processes that produce language knowledge in language speakers. Meanwhile, Dardjowidjodjo (2003: 225) states that language acquisition is the process of language mastery carried out by the child naturally when he learns his mother tongue.

Language acquisition in children is indeed one of the greatest and most amazing human achievements, that where it show how children speak, understand, and use language, but very little is known that language acquisition is very much determined by the complex interaction of aspects biological, cognitive and social maturity aspects. Acquisition of children's language can be said to have the characteristics of continuity, has a series of unity, which moves from saying a simple word to a combination of more complex words (syntax).

In the children's world, games are the main things in their minds, children cannot be separated from the name of play. By playing, children can develop imagination and get new experiences and new things so they can learn from the games.

Games are played mainly for entertainment, fun, but can also function as a means of training, education and simulation. Games can sharpen intelligence and brain skills in overcoming conflicts or artificial problems that exist in the game. Educational games can be used as an educational media or learning media. This type of game is commonly used to encourage users to learn while playing. Through this learning process, users can gain knowledge, so the educational game is a new breakthrough used in the world of education. In addition to this type of game because it combines learning and playing, this type of game can also be used to attract children's attention to learning.

\section{METHOD}

In this research, research design used is the Research and Development (R\&D) method. In this case, the developed media is an education game which consist of character culture based android system. The sample and population used were 50 people consisting of parents and early childhood from TK / PAUD in Ngawi District. Data collection techniques used by researchers are observation, interviews and questionnaire methods. Observations and questionnaire methods are used to determine the quality of the media and the interests of the respondents as well as the respondents' satisfaction with the educational game media of Android-based cultural characters. Interviews are used to describe the importance of the media in helping learning and how much the acquisition of children's language before and after using the media.

The data analysis technique was carried out by analyzing the results of observations and questionnaire evaluations as well as the results of the interviews then described in the form of numerical data. 


\section{Research Subject and Setting}

The research subjects are 50 Parents and 50 students of TK/PAUD. The setting of the research is in TK/PAUD at Ngawi District they are TK Dharma Wanita Pengkol 1, PAUD Rimba Putra, and RA Al Huda Wareng. The data source of this research is taken from observation of using media, interview and questionnaire. The focus of this research is the effect of using media and development of media.

\section{Data Collection Technique}

The data collection of this research is using instrument, because the research method used is Research and Development, so the main instrument is the application or media. The most basic method of data collection of this research is observation for obtaining the data. To support the research, the researcher also using supporting instrument to collect the data, they are form of observation sheet, interview and questionnaire.

The observation sheet is used to collect data which related to the process of teaching learning in the classroom. The interview is used for a number of purposes, they are: (1) Knowing unique information that not happened in the classroom activity, (2) Collecting many information from many persons, (3) Finding about things that researcher cannot observe.

The questionnaire is used to obtain the data about students' attitude on the implementation of active learning. It consists of ten number and given to the students after teaching learning process.

In this research, the researcher conduct the observation five times with the respondents of research are 50 parents and 50 children of TK Dharma Wanita Pengkol 1, PAUD Rimba Putra, and RA Al Huda Wareng. Parents complete the questionnaires and give some question for interview. The children are testing for getting data of language acquisition. Researcher make simple question to children and they answer it orally.

\section{Data Analysis}

Data analysis is a system to arrange the data and present to other. Miles and Huberman (1994) view that qualitative data analysis consists of data reduction, data display, and drawing conclusion. Data reduction is the stage of processing the "raw" data in order to be ready to be analyzed. The process form of data analysis are selecting, simplifying, focusing, summarizing, coding, sorting, or even making cluster of the themes.

Data display is the process of demonstrating the data either in the form of using media application, table and observation sheet. In the context of this research, the data were displayed in the form of conversational excerpts, classroom interaction and result of interview.

Both of the steps above, starting from reducing data to displaying data, are applied each time the researcher obtained data from one topic session. Based on these activities, the researcher make conclusion of the analysis and focused the attention in the subsequent data collection. The conclusion is written based on the analysis of the observation sheet, result of the interview, and documentation in the relation to the research by calculating and summarizing the data. 


\section{FINDINGS AND DISCUSSION}

\section{Preliminary Survey}

From the results of preliminary surveys conducted by the survey team obtained from the total number of respondents consisting of children aged 4-5 years totaling 50 people, the condition of language acquisition, especially in the field of culture is still very minimal as evidenced there are still children who do not know what is onthel, kebaya, gamelan and others. Children are less familiar with these words because they rarely find and hear the vocabulary. Some parents also rarely tell their children about Indonesian culture so their children do not understand and know about Indonesian culture.

The following is data acquisition table from preliminary study relates to the acquisition of children's language and educational game applications:

Table 1: Children's Vocabulary

\begin{tabular}{|c|c|c|c|c|}
\hline Age & \multicolumn{2}{|c|}{$\begin{array}{c}\text { Number of Common } \\
\text { Vocabulary }\end{array}$} & \multicolumn{2}{c|}{$\begin{array}{c}\text { Number of Culture } \\
\text { Vocabulary }\end{array}$} \\
\hline 4 Years & $>1.500$ Word & 23 children & $<100$ Word & 19 children \\
\hline 5 Years & $>2.500$ Word & 22 children & $<200$ Word & 15 children \\
\hline
\end{tabular}

Table 2: Game Knowing

\begin{tabular}{|l|c|c|}
\hline \multicolumn{1}{|c|}{ Kinds of Game } & Know & Don't Know \\
\hline PUBG & 43 & 7 \\
\hline Free Fire & 46 & 4 \\
\hline Mobile Legend & 50 & 0 \\
\hline Belajar Berhitung & 2 & 48 \\
\hline Mengenal Huruf & 5 & 45 \\
\hline Balita Cerdas & 0 & 50 \\
\hline Belajar Mengeja & 1 & 49 \\
\hline
\end{tabular}

From the data above it is known that the vocabulary of children in the field of culture is still lacking and needs to be added. Knowledge of the types of educational games is still very minimal and needs to be introduced as a medium for children's learning.

\section{Test Application}

In the application test there are several aspects that are the focus of data acquisition, namely the level of understanding of the use of the application and the level of preference for the application. In the first phase of the test there were 37 children who did not understand how to use the application and did not like the appearance of the application. This is because the application still has a menu that is lacking and causes children to be confused in using it and it looks less attractive to children. With this result the researchers made improvements to the application in accordance with the feedback given by parents. 
In the second phase of testing after making improvements there are 43 children who have begun to understand the use of the application and start liking the appearance of the application. But from the application test results there is still input from parents because the application cannot be installed on the type of cell phone with low specifications. The application can only be installed on a cellphone with high specifications and a high Android system. From these results the researchers and application developers will continue to strive to improve the application so that it can be used for learning media.

\section{Acquiring Early Childhood Language}

The results of the use of applications for children's language acquisition, especially in the field of culture there is significance. From the initial data of children who know little about vocabulary in terms of culture, after using the educational game media application there are $92 \%$ of children who have increased vocabulary in the field of culture. They also began to get to know Indonesian culture from dance, clothing, traditional houses and musical instruments and traditional vehicles in Indonesia.

\section{Data Analysis}

Data analysis was conducted to determine the feasibility of the media and the level of response from parents and children. The technique used by using the calculation as follows:

\section{Feasibility Analysis of Educational Game Media Based on Android}

The results of media studies were analyzed using the following formula:

Value $=$ Number of Scores obtained $\times 100 \%$

Maximum Number of Scores

With a rating scale as follows:

$1=$ Very bad

$2=$ bad

$3=$ Medium

$4=\operatorname{good}$

$5=$ Very good

With the following assessment standards:

$0 \%-20 \%=$ Not feasible

$21 \%-40 \%=$ Inadequate

$41 \%-60 \%=$ Fair enough

$61 \%-80 \%=$ Eligible

$81 \%-100 \%=$ Very feasible

Analysis of student, parent and teacher responses to Educational Game Media Analysis of student response questionnaire data was analyzed using the following formula:

$$
\text { Nilai }=\frac{\text { Jumlah Skor yang diperoleh }}{\text { Jumlah Skor maksimum }} x 100 \%
$$

With the following assessment standards:

$0 \%-20 \%=$ Very negative 


$$
\begin{aligned}
& 21 \%-40 \%=\text { negative } \\
& 41 \%-60 \%=\text { Quite positive } \\
& 61 \%-80 \%=\text { Positive } \\
& 81 \%-100 \%=\text { Very positive }
\end{aligned}
$$

Adaptation (Riduwan, 2006: 88)

From the calculation of the data obtained the following results:

Table 3: Media Feasibility Test and Response

\begin{tabular}{|c|c|c|c|c|}
\hline \multirow{2}{*}{ Media Test } & \multicolumn{2}{|c|}{ Media Feasibility } & \multicolumn{2}{c|}{ Respond } \\
\cline { 2 - 5 } & Feasible & Unfeasible & Positive & Negative \\
\hline Display & $44(88 \%)$ & $6(12 \%)$ & $47(94 \%)$ & $3(7 \%)$ \\
\hline Content & $42(84 \%)$ & $8(16 \%)$ & $40(80 \%)$ & $10(20 \%)$ \\
\hline System & $38(76 \%)$ & $12(24 \%)$ & $37(74 \%)$ & $13(26 \%)$ \\
\hline Benefit & $48(96 \%)$ & $2(4 \%)$ & $48(96 \%)$ & $2(4 \%)$ \\
\hline
\end{tabular}

Table 4: Children's Vocabulary Abilities

\begin{tabular}{|c|c|c|c|c|}
\hline Age & \multicolumn{3}{|c|}{$\begin{array}{c}\text { Number of Common } \\
\text { Vocabulary }\end{array}$} & Number of Culture Vocabulary \\
\hline 4 Years & $>1.500$ Word & 26 Children & $<100$ Word & 21 Children \\
\hline 5 Years & $>2.500$ Word & 24 Children & $<200$ Word & 25 Children \\
\hline
\end{tabular}

From this analysis it can be concluded that the development of a culture-based educational game media is acceptable and deserves to be a learning medium. And the media can help increase the number of vocabulary in the field of culture.

The above results are in line with research conducted by Vega Vitianingsih, (2016) with the title Educational Games as Learning Media for Early Childhood Education. The results of his research stated "This game can be used as an alternative media for early childhood education (PAUD) teacher learning in changing conventional learning into learning simulation games, so as to develop children's creativity, because in educational games have elements of challenge, accuracy, reasoning power and ethics".

Likewise, in accordance with research from Ghozi Dzikri Robbani, (2016) with the title of an Educational Game for the Introduction of English Vocabulary with Audio-Visual for Android-Based Early Childhood. Stating that "Educational Vocabulary Introductory Education Games are feasible and effective as an alternative learning media for young children in improving language skills".

\section{CONCLUSION}

From the results of the research and discussion above it can be concluded that the development of an educational game media based on the character of the Android system culture is feasible and able to increase the acquisition of early childhood language. This media can be used for kindergarten / PAUD language learning that requires new media for early language learning, especially in the 
field of culture. Besides this media can introduce Indonesian culture to early childhood from now on.

\section{REFERENCES}

Abin Syamsudin Makmun. (2004). Psikologi Kependidikan Perangkat sistem Pengajaran Moodul. Bandung: PT Remaja Rosdakarya.

Borg \& Gall. (1979). Educational Research: an introduction. New York: Longman, Inc

Dardjowidjojo, Soenjono. (2010). Psikolinguistik: Pengantar Pemahaman Manusia Edisi Kedua. Jakarta: Yayasan Obor Indonesia Unika Atma Jaya.

Daryanto. (2009). Panduan Proses Pembelajaran Kreatif dan Inovatif. Jakarta: AV Publisher.

Jihad, Asep dan A. Haris. (2013). Evaluasi Pembelajaran. Yogyakarta: Multi Persindo.

Muslimin Ibrahim. (2001). Pengembangan Perangkat Pembelajaran. Jakarta: Depatemen Pendidikan Nasional.

Riduwan. (2006). Metode dan Teknik Menyusun Tesis. Bandung: Alfabeta.

Robbani, Ghozi Dzikri. (2016). Game Edukasi Pengenalan Kosa Kata Bahasa Inggris dengan Audio-Visual untuk Anak Usia Dini Berbasis Android. Skripsi. Pendidikan Teknik Informatika dan Komputer. Jurusan Teknik Elektro. Fakultas Teknik. Universitas Negeri Semarang.

Sadiman, Arif. (1996). Media Pendidikan Pengertian Pengembangan dan Pemanfaatannya. Jakarta: Raja Grafindo Persada.

Sugiyono. (2015). Metode Penelitian Pendidikan. Bandung: Alfabeta.

Vega Vitianingsih, A. (2016). Game Edukasi Sebagai Media Pembelajaran Pendidikan Anak Usia Dini. Jurnal INFORM, l(1).

Wina Sanjaya. (2014). Strategi Pembelajaran Berorientasi Standar Proses Pendidikan. Jakarta: Kencana. 